\title{
In vitro antimicrobial susceptibility in clinical isolates of Enterococcus species
}

\author{
Ernesto C alderón-Jaimes, MC, MSP, (1) José Luis Arredondo-García, MC, ${ }_{1}^{(2)}$ \\ Felipe A guilar-Ituarte, MC, ${ }^{(2,3)}$ Pilar García-Roca, Q FB. . $^{(1)}$
}

\begin{abstract}
Calderón-Jaimes E,Arredondo-García JL, Aguilar-Ituarte F, García-Roca P. In vitro antimicrobial susceptibility in clinical isolates of Enterococcus species. Salud Publica Mex 2003;45:96-101. The English version of this paper is available too at: http://www.insp.mx/salud/index.html
\end{abstract}

\begin{abstract}
A bstract
Objective.To describe the antimicrobial activity of several antimicrobial agents against 97 clinical significant isolates of Enterococcus spp. Material and Methods During a 2year prospective study at Instituto $\mathrm{N}$ acional de Pediatria ( $N$ ational Institute of Pediatrics) in Mexico C ity. N inety seven strains of Enterococcus spp. (60 E. faecalis and $37 \mathrm{E}$. faecium) were tested against 11 antibiotics. Susceptibility tests were performed with agar, according to the standards of the $\mathrm{sN}$ ational Committee for Clinical Laboratory Standards (N CC LS). Isolates were screened for high-level resistance (HLR) to $\beta$-lactams, aminoglycosides, glycopeptides and other antibiotics, as well as for vancomycin-phenotypes. D ifferences between proportions were evaluated with $\chi^{2}$ of Fisher exact fest. Results 0 verall resistance rates to the antibiotics tested were: $17 / 97$ (17.5\%) to penicillin, ampicillin, amoxicillin-clavulanate and imipenem. There was neither HLR nor $\beta$-lactamase production; 74/97 (48.4\%) were resistant to erythromycin; $60 \%$ to ciprofloxacin; $31 / 97$ $(32 \%)$ to gentamicin, and $55 / 97(56.7 \%)$ to streptomycin. Seven strains were vanco mycin-resistant entero cocci (VRE), all of them identified as E. faecium; 5/7 with Van $A$ and 2/7 with Van B phenotypes. All the isolates were susceptible to linezolid.The difference in susceptibility among species was significant. Conclusions Mutidrug-resistant enterococci is a real problem and continuous surveillance is necessary.The
\end{abstract}

\author{
Calderón-Jaimes E,Arredondo-García JL, \\ Aguilar-Ituarte F, García-Roca P. \\ Susceptibilidad antimicrobiana in vitro \\ en aislamientos clínicos de Enterococcus species. \\ Salud Publica Mex 2003;45:96-101. \\ El texto completo ens inglés de este artículo también \\ está disponible en: http://www.insp.mx/salud/index.html
}

\section{Resumen}

Objectivo. Describir la actividad antimicrobiana de varios antibióticos, contra 97 cepas de Enterococcus spp., consideradas como aislamientos clínicamente significativos. Material y métodos. En un estudio prospectivo de dos años, (enero de 1998 a diciembre de 1999) hecho en el Instituto $\mathrm{N}$ acional de Pediatría en la Ciudad de México, se procesaron 97 cepas de Enterococcus (60 de Enterococcus faecalis y 37 de Enterococcus faecium, contra 11 antibióticos. La prueba de susceptibilidad se elaboró con agar, de acuerdo con los estándares del Comité $\mathrm{N}$ acional para el Laboratorio C línico (N CC LS). Todos los aislamientos fueron probados para determinar la resistencia elevada en contra de $\beta$-lactámicos, aminoglucósidos y glico péptidos.A simismo, se determinó el fenotipo de resistencia hacia la vancomicina. Se evaluaron diferencias de proporciones con $\chi^{2} 0$ prueba exacta de Fisher. Resultados La resistencia en general hacia los antibióticos probados fue 17/97 (17.5\%) a penicilina, ampicilina, amoxicilina-clavulanato e imipenem. No se encontró resistencia elevada ni presencia de producción de $\beta$-lactamasas; 74/97 (48.4\%) fueron resistentes a eritromicina, $60 \%$ resistentes a ciprofloxacina, 31/97 (32\%) resistentes a gentamicina y 55/97 (56.7\%) resistentes a estreptomicina. Siete cepas fueron resistentes a vancomicina, todas ellas E. faecium; 5/7 con el fenotipo A y 2/7 con el fenotipo B. Todas las cepas aisladas fueron susceptibles al

We acknowledge the partial support of Pharmacia and U pjohn, Kalamazoo, Mich. (D r. Susana Suárez).

(1) Departamento de Inmunoquímica y Biología Celular, Hospital Infantil de México Federico Gómez, México, D.F., México.

(2) Unidad de Investigación Clínica, Instituto N acional de Pediatría, México, D.F., México.

(3) Departamento de Infectología, Hospital Infantil de México Federico Gómez, México, D.F., México.

Received on: May 20,2002 • Accepted on: January 9,2003

Address reprint requests to: Ernesto Calderón-Jaimes. D epartamento de Inmunoquímica y Biología Celular, Edificio Mundet Tercer Piso, Hospital Infantil de México Federico Gómez. Calle Dr. Márquez 162, Colonia D octores, 06720, México, D.F., México.

e.mail: ecalderj@yahoo.com 
microbiology laboratory is the first line of defense against the spread of multiantibio tic-resistan entero cocci in the hospital environment .All the strains recovered should be tested for susceptibility to ampicillin, strepto mycin, gentamicin and glycopeptides. The English version of this paper is available to o at: http://ww w.insp.mx/salud/index.html

Key words: drug resistance, microbial; enterobacteriaceae infections; Mexico linezolid. La diferencia en la susceptibilidad antimicrobiana entre las especies fue significativa. Conclusiones La resistencia antimicrobiana múltiple de Enterococcus spp. es un problema real y es necesaria su vigilancia. El laboratorio de microbiolo gía es la primera línea de defensa en contra de la diseminación de enterococos con resistencia múltiple en el ambiente hospitalario.Todas las cepas aisladas deberían ser probadas en contra de ampicilina, estreptomicina, gentamicina y glicopéptidos. El texto completo en inglés de este artículo también está disponible en: http://w w w.insp.mx/salud/index.html

Palabras clave: resistencia microbiana a las dro gas; infecciones por enterobacteriaceae; México
E nterococci are normal inhabitants of the gastroin testinal tract and part of the normal intestinal flora. They are not particularly pathogenic organisms in humans. Despite their lack of pathogenicity, enterococci have emerged as significant nosocomial pathogens. ${ }^{1-9}$ Enterococci are also commonly recovered from infections of the abdomen, the pelvis, the biliary tract and wounds. Polymicrobial flora is common in these sites. Enterococci cause infections of other sites less frequently, for example, in bone, joints and the meninges. ${ }^{3,4,10-13}$

Progress in medical technology, such as the use of various intravascular access devices, magnified the impact of organisms of relatively low virulence, such as enterococci. ${ }^{13}$ Of critical importance is the intensive use of broad-spectrum antibiotics in hospitals, which fosters a selective pressure favoring the growth of intrinsically drug-resistant commensal organisms like enterococci. ${ }^{6,14-18}$

Resistance to a number of antimicrobial drugs is characteristic of the genus Enterococcus, although some species are more intrinsically resistant than others.

The role of enterococci as a cause of infections has become increasingly important, not only because of their documented pathogenic potential, but also because of the increasing antimicrobial resistance of some strains, especially resistance to vancomycin (VRE) ${ }^{14}$ Increasing use of parenteral third-generation cephalosporins and vancomycin for the treatment of intravascular device-related infections might have a role in developing enterococcal resistance. ${ }^{6}$ Observations of vancomycin-resistant strains have revealed the presence of several different phenotypes of glycopeptide resistance. ${ }^{17}$

A number of newly-acquired mechanisms of resistance have emerged or become more frequent in Enterococcus species during the past decade, including high-level aminoglycoside resistance, beta-lactamase production, high-level ampicillin resistance, and vancomycin resistance. In United States hospitals, enterococci have become the second most common nosocomial pathogen overall, according to Nationwide Surveillance data. ${ }^{10,19}$ In our study, 97 isolates from pediatric patients with Enterococcus species considered as clinically significant strains, were tested against several antimicrobials, to determine the in vitro activity of each agent as well as the phenotype in those with VRE.

\section{Material and Methods}

From January 1998 to December 1999, a 2-year prospective study was carried out at Instituto Nacional de Pediatria (National Institute of Pediatrics), a teaching and referral third-level hospital in Mexico City. Only serious infections were included in the study: endocarditis $(\mathrm{n}=4)$; primary bacteremia (unknown source) $(\mathrm{n}=23)$; catheter- related bacteremia (24); empyema (4); urosepsis (9); meningitis and / or ventriculitis (11); intrabdominal infection (3); and deep surgical wound infection (abscess) (19).

Clinical definition. Clinical significant bacteremia or infection due to Enterococcus spp., was defined by isolation of either species from $\geq 2$ blood cultures or from a single blood culture, if there was a clinically apparent and / or culture-positive source of infection.

Bacterial strains. A total of 97 isolates were collected, 60 of them were Enterococcus faecalis and 37 were Enterococcus faecium. All of them were stored in doublestrength skim milk (Difco,Labs. Detroit, Mich.) at $-70^{\circ} \mathrm{C}$.

Enterococcal isolates were identified using driedovernight gram-positive combination panels in the MicroScan WalkAway 96 Instrument (Dade MicroScan, Inc., West Sacramento, CA). Species identification was confirmed by conventional microbiological testing. ${ }^{20,21}$ 
Prior to testing for susceptibility, isolates were thawed and subcultured twice to ensure purity and viability. Antimicrobials were supplied from the manufacturers as laboratory powders of known potency; stock solutions were prepared as recommended by the manufacturers. Antimicrobial used were: Penicillin G potassium, ampicillin and amoxicillin-clavulanate, imipenem, erythromycin, streptomycin, gentamicin, ciprofloxacin, teicoplanin, vancomycin and linezolid.

Antimicrobial susceptibility testing. The minimal inhibitory concentration (MIC) was determined in duplicate by the broth microdilution method in Mueller-Hinton broth (Difco, Mexico City, Mexico) supplemented with $10 \mathrm{mg}$ of $\mathrm{MgCl}_{2} / 1$ and $20 \mathrm{mg}$ of $\mathrm{CaCl}_{2} / 1$, with a final inoculum of $1.5 \times 10^{5} \mathrm{CFU} / \mathrm{ml}$, as recommended by the National Committee for Clinical Laboratory standards (NCCLS). ${ }^{22}$ All plates were incubated at $35^{\circ} \mathrm{C}$ for $24 \mathrm{~h}$ in ambient air before determination of Minimal Inhibitory Concentration (MIC) values. The plates were visually read. NCCLS breakpoints were used to interpret MIC data. ${ }^{22}$ Appropriate quality control was performed by use of Enterococcus faecalis ATCC-29212 (vancomycin susceptible). Linezolid is an investigational drug. NCCLS considered strains with a MIC $\leq 2 \mu \mathrm{g} / \mathrm{ml}$ as susceptible, those with a MIC $=4 \mu \mathrm{g} / \mathrm{ml}$ as intermediate, and those with a MIC $\geq 8 \mu \mathrm{g} / \mathrm{ml}$ as resistant. ${ }^{23}$

Screening for beta-lactamase production was done using Cefinase disk methodology (a chromogenic substrate nitrocefin, Cefinase, BBL, Microbiology Systems, Cockeysville, MD).
High-level aminoglycoside resistance (HLAR). All the strains with a MIC $\geq 64 \mu \mathrm{g} / \mathrm{ml}$ to gentamicin and streptomycin were used to screen for HLAR. Those strains suspected to be HLAR were confirmed by broth tube dilution using brain-heart infusion broth with 500 and $1000 \mu \mathrm{g} / \mathrm{ml}$ concentrations of gentamicin, as well as with 1000 and $2000 \mu \mathrm{g} / \mathrm{ml}$ concentrations of streptomycin.

Phenotypes. The Van A phenotype include enterococci resistant to high levels of vancomycin (MIC $\geq 64$ / $\mathrm{ml}$ ) and teicoplanin (MIC $\geq 8 \mu \mathrm{g} / \mathrm{ml}$ ). This resistance is vancomycin- and/or teicoplanin- inducible. ${ }^{18}$ Van $B$ organisms are resistant to a range of vancomycin concentrations, from 4 to $\geq 1024 \mu \mathrm{g} / \mathrm{ml}$; they typically retain their susceptibility to teicoplanin. This resistance is also inducible by vancomycin but not by teicoplanin. ${ }^{18}$ Differences between proportions were evaluated with the $\chi^{2}$ or Fisher exact test (as appropriate).

\section{Results}

A total of 97 clinical isolates of Enterococcus spp. (60 E. faecalis and $37 \mathrm{E}$. faecium) were collected, identified, and analyzed over a 24-month study period.

Table I shows the in vitro activity of antimicrobial agents that were tested according to different species.

$\beta$-lactam resistance. 5/60 (8.3\%) E. faecalis and 27/37 $(73.0 \%)$ E. faecium were resistant (overall 32/97; 33\%) to penicillin; $2 / 60(3.3 \%)$ E. faecalis and $15 / 37(40.5 \%)$ E. faecium were resistant (overall 17/97, 17.5\%) to am-

Table I

IN VITRO ACTIVITY OF SEVERAL ANTIMICROBIAL AGENTS AGAINST 97 ISOLATES OF ENTEROCOCCUS FAECALIS and Enterococcus faecium. National Institute of Pediatrics, Mexico City, 1998-1999

\begin{tabular}{|c|c|c|c|c|c|c|}
\hline & \multicolumn{3}{|c|}{ E. faecalis (60) } & \multicolumn{3}{|c|}{ E. faecium (37) } \\
\hline Antimicrobials & $\overline{\text { MIC range }}$ & $\mathrm{MIC}_{50} / \mathrm{MIC}_{90}$ & $\%$ & $\overline{\mathrm{MIC}}$ range & $\mathrm{MIC}_{50} / \mathrm{MIC}_{90}$ & $\%$ \\
\hline Penicillin & $1->16$ & $4 />16$ & 91.6 & $1->16$ & $4 />16$ & 27.0 \\
\hline Ampicillin & $<0.25->16$ & $1 / 4$ & 96.6 & $0.05->16$ & $2 / 16$ & 59.5 \\
\hline Amoxicillin/clav & $<0.25->16$ & $1 / 4$ & 96.6 & $0.5->16$ & $2 />16$ & 59.4 \\
\hline Imipenem & $0.5->8$ & $2 / 4$ & - & $\leq 0.25->8$ & $>8 />8$ & - \\
\hline Erytromycin & $<0.25->8$ & $>8 />8$ & - & $0.5->32$ & $>4 />8$ & - \\
\hline Streptomycin & $<0.5->128$ & $0.5 />128$ & 46.6 & $<0.5->128$ & $0.5 />128$ & 37.8 \\
\hline Gentamicin & $\leq 0.5->128$ & $0.5 />128$ & 75.0 & $<0.5->128$ & $0.5 />128$ & 56.7 \\
\hline Ciprofloxacin & $<0.5->2$ & $0.5 />2$ & 33.3 & $0.5->2$ & $1 / 2$ & 27.0 \\
\hline Teicoplanin & $\leq 0.25->16$ & $0.25 / 0.5$ & 100 & $0.5->16$ & $0.25 />16$ & 86.4 \\
\hline Vancomycin & $0.5-8$ & $0.5 / 1$ & 100 & $0.5-16$ & $0.5 />16$ & 81.0 \\
\hline Linezolid & $\leq 0.25-2$ & $0.5 / 1$ & 100 & $<0.25->2$ & $0.5 / \geq 4$ & 100 \\
\hline
\end{tabular}

MIC s in $\mu \mathrm{g} / \mathrm{ml}, \%=$ Percent susceptible determined using N CCLS interpretative criteria; (-) no interpretative criteria published by the N CCLS 
picillin and amoxicillin-clavulanate; $15 / 97$ (15.4\%) -all of them E. faecium- were resistant to imipenem. Resistance between species against $\beta$-lactams was significant. There was neither high-level penicillin resistance nor $\beta$-lactamase production among the clinical strains tested.

High-level aminoglycoside resistance. Fifthteen of sixty $(25.0 \%)$ E. faecalis and 16/37 (43.3\%) E. faecium were resistant (overall 31/97;32\%) to gentamicin; 32/60 (53.4 $\%)$ E. faecalis and $23 / 37(62.1 \%)$ E. faecium were resistant (overall 55/97; 56.7\%) to streptomycin. Resistance to aminoglycosides between species was significant. Vancomicin-resistant enterococci. Seven strains were resistant to vancomycin, all of them E. faecium; 5 of 7 strains were also resistant to teicoplanin. All E. faecalis strains were susceptible to vancomycin and teicoplanin.

Phenotypes. Five of seven VRE isolates exhibited the Van A phenotype, and 2/7 exhibited the phenotype Van B.

Other antimicrobials. Erythromycin inhibited more than $50 \%$ of all strains at or below their respective susceptible breakpoint concentrations. More than $60 \%$ of the strains tested were resistant to ciprofloxacin. Notably, $100 \%$ of all the isolates tested were inhibited by $\leq 4 \mu \mathrm{g} / \mathrm{ml}$ of linezolid.

\section{Discussion}

Enterococci are not generally regarded as highly virulent bacterial pathogens, however, resistance to many antimicrobial drugs complicates the treatment of enterococcal infections. Acquired resistance to high concentrations of ampicillin, aminoglycoside, and glycopeptide antibiotics, specifically vancomycin, has exacerbated this problem. $6,8,13,14,18,24,25$

In the last decade enterococci have become recognized as leading causes of nosocomial bacteremia, surgical wound infections, and urinary tract infections.

Two types of enterococci cause infections: a) those originating from patients' native flora, which are unlikely to possess resistance beyond that intrinsic to the genus, and to be spread between patients from bed to bed, and $b$ ) isolates that possess multiple antibiotic resistance traits and are capable of nosocomial transmission. The therapeutic challenge of multiple-drug resistance enterococci has brought their role as important nosocomial pathogens into sharper focus.

Although E. faecium strains are resistant to ampicillin, aminoglycosides, and glycopeptides more than E. faecalis strains, the relative proportion of infections caused by these species has not dramatically changed in recent years. ${ }^{14}$
Different patterns of resistance have been informed from many countries. ${ }^{18}$ That information is scarce in Mexico, particularly in pediatric patients. ${ }^{26,27}$ In this study the activity of several antimicrobial agents against 97 clinical isolates is reported.

Considerable resistance of $\mathrm{E}$. faecium isolates to most of the antibiotics tested was demonstrated during the study period.

The results of this study confirm that E. faecalis strains resistant to ampicillin and vancomycin are uncommon; in contrast, E. faecium strains resistant to vancomycin (7/ 37 strains) and ampicillin (15/37 strains), increased alarmingly. This observation is similar to those reported by other authors. ${ }^{13,14,28-30}$

At least for E. feacalis and E. falcium against penicillin, ampicillin and imipenem.

High-level resistance to aminoglycosides is a real problem, this resistance overcomes the synergy of killing combination therapy. Ampicillin and vancomycin are not bactericidal unless combined with an aminoglycoside. ${ }^{10,12,18}$ High-level gentamicin resistance is most often associated with high-level resistance to all alternative aminoglycosides

Since enterococcal resistance to gentamicin and streptomycin occurs by different mechanisms, it is important to test susceptibility to both agents. Enterococci with HLR to streptomycin are susceptible to gentamicin. Gentamicin resistance is a good predictor of resistance to other aminoglycosides; also, ampicillin resistance is a predictor of imipenem resistance..$^{31-33}$

Glycopeptide-resistance in Enterococcus spp. (7/97 or $7.2 \%$ ) is higher than that found by Miranda and cols.; 5 /235 (2.12\%) in E.faecalis and E.faecium strains. ${ }^{26}$ Those isolates confirm the various levels of resistance to vancomycin and teicoplanin.

In this study, five of seven isolates of E. faecium were phenotype Van A and the other 2 were phenotype Van B. It is useful to identify which species are vancomycin-resistant in enterococcal isolates. Identification of Van A organisms has implications for treatment and infection control. ${ }^{34,35}$

Other studies on VRE clinical isolates found that most were Van A phenotype strains of E. faecium; they were associated with outbreaks in special wards with immunocompromised patients on long term antimicrobial regimens, with extended lengths of stay and higher severity of illness scores..$^{36-38}$

Several limitations of the data from this study make firm conclusions problematic. First, all of the microorganisms tested came from a single institution. Second, a relatively small number of E. faecium and $E$. faecalis were tested; it is possible that these strains mig- 
ht represent only a few clones. Third, no species other than E. faecalis and E. faecium were included.

Once vancomycin-resistant enterococci are established in the hospital environment, their frequent resistance to multiple antibiotics make it difficult to avoid further selective pressure in their favor. Enterococcal infections tend to occur in more debilitated or seriously ill hospitalized patients. Mortality in patients with VRE bacteremia may reach 60-70\%.3,14 From 1989 through 1997, the percentage of infections caused by VRE increased from 0.4 to $23.2 \%$ among patients in the intensive care unit (ICU), and from 0.3 to $15.4 \%$ among patients not in the ICU. ${ }^{2}$

Because most enterococci are resistant to the bactericidal activity of $\beta$-lactam and glycopeptide antibiotics, bactericidal synergy between one of these antibiotics and an aminoglycoside is needed to treat most serious enterococcal infections. The synergistic bactericidal effect between aminoglycosides and $\beta$-lactam or glycopeptide antibiotics is lost if there is highlevel resistance to either class of drug. The increasing use of parenteral vancomycin for the treatment of intravascular device-related infections might have a role in enterococcal resistance.

Treatment of multidrug-resistant enterococci is under an investigational new drug program for treatment of patients with life-threatening infection due to vancomycin-resistant $\mathrm{E}$. faecium bacteremia. There has been a considerable effort to develop alternative agents; for example, dalfopristin-quinupristin is a streptogramin antibiotic that has been studied in the treatment of infections due to vancomycin-resistant E. faecium. Other investigational agents with activity in vitro against Enterococcus spp. susceptible or resistant to glycopeptides include the oxazolidinones. These are a new class of synthetic antibiotics with good antienterococcal activity and are different from any other class. Mechanisms of resistance that affect antibiotics in current clinical use do not affect the activities of oxazolidinones. Linezolid is one of the investigational agents. ${ }^{39,40}$ In this study linezolid showed excellent activity against multiantibiotic- resistant enterococci. Clinical efficacy and safety studies are needed to determine its real utility. Linezolid has recently been approved by the Food and Drug Administration.

The microbiology laboratory is the first line of defense against the spread of multiantibiotic-resistant enterococci in the hospital environment. Cooperation and communication between the laboratory and the infection control program is essential in recognizing enterococci-resistant isolates from colonization and infection. All of the strains recovered should be tested for susceptibility to ampicillin, streptomycin, gentamicin, and glycopeptides.

It will be necessary to study additional E. faecalis and E. faecium strains from different hospitals and, if possible to include less common enterococcal species such as E. gallinarum and E. casseliflavus, which are relatively infrequent causes of human infections but they have intrinsic resistance to low concentrations of vancomycin.

\section{Acknowledgements}

The authors are grateful to Dr. L.E. Espinosa de los Monteros, M. Sc. Norma Velázquez, Dr. Renata Avila, and Esther Lombardo for their technical assistance to store the samples and ensure the purity and viability of strains tested.

\section{References}

1. Schaberg DR, Culver DH, Gaynes RP. Mayor trends in the microbial etiology of nosocomial infection. Am J Med 91;(suppl 3B):72S-75S.

2. Centers for Disease Control and Prevention. N osocomial enterococci resistant to vancomycin-United States, 1989-1993. MMW R Morb Mortal W kly Rep 1993;42:597-599.

3. Tornieporth N, Roberts RB, John J, Hafnier A, Riley LW. Risk factors associated with vancomycin-resistant Enterococcus faecium infection or colonization in 145 matched case patients and control patients. Clin Infect $D$ is 1996;23:767-772.

4. Edmond MB, $O$ ber JF, D awson JD, W einbaurri DC, W enzel RP.Vancomycin-resistant enterococcal bacteremia: $\mathrm{N}$ atural history and attributable mortality. Clin Infect D is 1996;23:1234-1239.

5. Elio poulos G M.Vancomycin-resistant enterococci: Mechanism and clinical relevance. Infect D is C lin N orth Am 1997;11:851-865.

6. Murray BE.The life and times of the enterococcus. Clin Microbiol Rev 1990;3:45-65.

7. Rubin L, Tucci V, Cerenado E, Elioponlos G, Isenberg H.Vancomycinresistant Enterococcus faecium in hospitalized children. Infect Control Hosp Epidemiol 1992;13:700-705.

8. Fridkin SK, Gaynes RP.Antimicrobial resistance in intensive care units. Clin Chest Med 1999;20:303-316.

9. Patterson JE, Sweeney AH, Simms M, C arley N, Mangi R, Sabetta J et al. An analysis of 110 serious enterococcal Infections. Epidemiology, antibiotic susceptibility, and outcome. Medicine 1995;74:191-200.

10. Ross TW. Infectious disease challenge:Vancomycin-resistant enterococcus and staphylococcus. D rug Topics 1998;142:76-83.

11. Murray BE. Vancomycin-resistant enterococci. Am J Med 1997;102: 284-293.

12. Murray BE. Diversity among multidrug-resistant enterococci. Emerg Infect $D$ is 1998:4:37-47.

13. Gold HS. Vancomycin-resistant enterococci: Mechanisms and clinical observations. C lin Infect D is 2001;33:210-219.

14. Huycke MM, Sahm DF, G ilmore MS. Multiple-drug resistant enterococci:The nature of the problem and an agenda for the future. Emerg Infect $D$ is 1998:4:239-249. 
15. HodgesTR, Zighelboim-D aum S, Elio pulus GM,W ennerstein CB, Moellering RC. Antimicrobial susceptibility changes in Enterococcus faecalis following various penicillin exposure regimens. Antimicrob Agents $\mathrm{Che-}$ mother 1992;36:121-125.

16. Moellering RC. Vancomycin-resistant enterococci. Clin Infect Dis 1998;26:1196-1199.

17. Gold HS, Moellering RC. D rug therapy:Antimicrobial-drug resistance. N Engl J Med 1996;335:1445-1454.

18. Centinkaya $Y$, Falk P, Mayhall CG. Vancomycin-resistant enterococci. Clin Microbiol Rev 2000;13:686-707.

19. Perl TM. The threat of vancomycin resistance. Am J Med. 1999;106: 265-37S.

20. Facklam RR, Sham D F, Teixeira LM. Enterococcus. En: Murray PR, Baron E), Pfaller MA, Tenover FC,Yolken RA, ed. Manual of clinical microbiology. $7^{\text {th }}$ ed.W ashington, DC :A merican Society for Microbiology, 1999:297-305. 21. Facklam RR, Collin MD. Identification of Enterococcus species isolated from human infections by a conventional test scheme. J Clin Microbiol 1989;27:731-734.

22. N ational Committee for Clinical Laboratory Standards. Methods for dilution antimicrobial susceptibility tests for bacteria that grow aerobicaIly. A pproved standard- $5^{\text {th }}$ ed. W ayne (PA): N CCLS, 2000; D ocument M7A-5, 27.

23. N ational Committee for Clinical Laboratory Standards. Performance standards for antimicrobial susceptibility testing. Twelfth Informational Supplement. W ayne (PA): N CCLS, 2002; D ocument M100-S12.

24. Bonten MJ, Slaughter S, A mbergen AW, Hayden MK, van Voorhis J, N athan $C$ et al. The role of "colonization pressure" in the spread of vancomycin-resistant enterococci: An important infection control variable. Arch Intern Med 1998;158:1127-1132.

25. Palmer SM, Ryback MJ.Vancomycin-resistant enterocci. Pharmacotherapy 1996;16:819-829.

26. Miranda G, Lee L, Kelly C, Solórzano F, Leaños B, Muñoz 0 et al.Antimicrobial resistance from enterococci in a pediatric hospital. Plasmids in Enterococcus faecalis isolates with high-level gentamicin and streptomycin resistance. Arch Med Res 2001;32:159-163.

27. Sifuentes-O sornio J, Ponce deLeón A, Muñoz-Trejo T,Villalobos-Zapata Y, O ntiveros-Rodríguez C, Gómez-Roldan C. Antimicrobial susceptibility patterns and high-level gentamicin resistance among enterococci isolated in a Mexican tertiary care center. Rev Invest Clin 1996:48:91-96.

28. Pfaller MA, Jones RN, D oern GV, Kugler K, the SEN TRY participants Group. Bacterial pathogens isolated from patients with blood stream infections: Frequencies of ocurrence and antimicrobial susceptibility patterns from the SEN TRY A ntimicrobial Surveillance Program (U nited States and Canada, 1997). Antimicrob Agents Chemother 1998:42:1762-1770.
29. Sader HS, Jones RN , Gales AC, W inokur P, Kugler KC, Pfaller MA et al. Antimicrobial susceptibility patterns for pathogens isolated from patients in Latin A merican medical centers with a diagnosis of pneumonia:A nalysis of results from the SEN TRY. Antimicrobial Surveillance Program (1997), SEN TRY Latin American Study Group. Diagn Microbiol Infect Dis 1998:32:289-301.

30. G ales AC, Jones RN, Pfaller MA, G ordon KA, Sader HS, Sampaio J et al. Two-year assessment of the pathogen frequency and antimicrobial resistance patterns among organisms isolated from skin and soft tissue infections in Latin A merican hospitals: Result from the SEN TRY Antimicrobial Surveillance Program,1997-98. Int J Infect D is 2000;4:75-84.

31. Arthur M, Reynolds PE, D epardieu F, C orvalin P. Mechanisms of glycopeptide resistance in enterococci. Infect $D$ is 1996;32:11-16.

32. Ferretti JJ, Gilmore KS, Courvalin P. N ucleotide sequence analysis of the gene specifying the bifunctional $6^{\prime}$-aminoglycoside acetyltransferase 2 "-aminoglycoside phosphotransferase enzyme in Streptococcus faecalis and identification and cloning of gene regions specifying the two activities. J Bacteriol 1986;167:631-638.

33.W einstein MP. C omparative evaluation of penicillin, ampicillin, and imipenem MICs and susceptibility breakpoints for vancomycin-susceptible and vancomycin-resistant Enterococcus faecalis and Enterococcus faecium. J Clin Microbiol 2001;39:2729-2731.

34. Herman DJ, Gerdin DN . Screening and treatment of infections caused by resistant enterococci. Antimicrob A gent Chemother 1991;35:215-219. 35. Q uintiliani R, Evers $S$, Courvalin P. The van $B$ gene confers various levels of self-transferable resistance to vancomycin in enterococci.J Infect $D$ is 1993;167:1220-1223.

36. G arbutt J.Ventrapragada M, Littenberg B, Mundy LM. Association between resistance to vancomycin and death in cases of Enterococcus faecium bacteremia. C lin Infect D is 2000;30:466-472.

37. Lautenback E, Bilker W B, Brennan PJ. Enterococcal bacteremia: Risk factors for vancomycin resistance and predictors of mortality. Infect C ontrol Hosp Epidemiol 1999;20:318-323.

38. Lucas G, Lechtzin N , Puryear W, Yaul, Flexner C, Moore R.Vancomycinresistant and vancomycin-susceptible enterococcal bacteremia: $C$ omparison of clinical features and outcomes. C lin Infect D is 1998;26:1127-1133. 39. N askin GA, Siddiqui F, Stosor V, Hacek D, Peterson LR. In vitro activities of linezolid against important gram-positive bacterial pathogens including vancomycin-resistant enterococci.Antimicrob A gents $\mathrm{C}$ hemother 1999;43:2059-2062

40. Clement D, Markham A. Linezolid. D rug 2000;59: 815-827. 